\title{
Behavioural guidance of yellow-stage American eel Anguilla rostrata with a light- emitting diode device
}

\author{
Chris K. Elvidge ${ }^{1,4, *}$, Matthew I. Ford ${ }^{1}$, Thomas C. Pratt ${ }^{2}$, Karen E. Smokorowski ${ }^{2}$, \\ Michael Sills ${ }^{3}$, Paul H. Patrick ${ }^{3}$, Steven J. Cooke ${ }^{1}$ \\ ${ }^{1}$ Fish Ecology and Conservation Physiology Laboratory, Department of Biology, Carleton University, Ottawa, ON, K1S 5B6, \\ Canada \\ ${ }^{2}$ Great Lakes Laboratory for Fisheries and Aquatic Sciences, Fisheries and Oceans Canada, Sault Ste Marie, ON, P6A 2E5, \\ Canada \\ ${ }^{3}$ ATET-TECH Incorporated, Thornhill, ON, L4J 6X8, Canada \\ ${ }^{4}$ Present address: Department of Biology, University of Eastern Finland, PO Box 111, Joensuu, 81010 Finland
}

\begin{abstract}
Providing safe downstream passage for outmigrating freshwater eels around hydroelectric facilities, especially on large river systems, is a daunting challenge. With engineering limitations on the installation of physical barriers, behavioural guidance research is needed to steer outmigrating eels towards safe passage or collection facilities. We exposed late, yellow-stage American eel Anguilla rostrata to different colours and strobing frequency of light-emitting diode (LED) light, or to unlit control trials, in y-maze dichotomous choice tests. Eels demonstrated initial attraction towards the y-maze structure and entered the dark (control) side more often and for a longer duration compared to the illuminated side. Blue light strobing at $30 \mathrm{~Hz}$ elicited the greatest initial avoidance response and eels spent less time on the light side with this treatment, and we recommend that this setting be tested further under field conditions. Although the initial avoidance of all light settings attenuated over the 5 min observations, this attenuation may be less relevant when eels are engaged in active migration, and thus may provide a viable means of guiding eels to safe outmigration paths.
\end{abstract}

KEY WORDS: Hydropower · Turbines · Outmigration · Light guidance device $\cdot$ Strobing lights · LED

\section{INTRODUCTION}

Atlantic eels (including both the European eel Anguilla anguilla and the American eel A. rostrata) are iconic, facultatively catadromous fish species, historically targeted by commercial, recreational, and indigenous fishers (Cairns et al. 2014, Dekker \& Beaulaton 2016). Atlantic eels are obligate migrants, and their available habitat has been greatly reduced across much of their range due to human-made barriers (Feunteun 2002, Pratt et al. 2014). As a consequence of severe population declines, the Interna-

${ }^{*}$ Corresponding author: chris.k.elvidge@gmail.com tional Union for Conservation of Nature (IUCN) considers the European eel to be Critically Endangered (Jacoby \& Gollock 2014). The American eel has declined less than its European counterpart, but is still classified as Endangered by the IUCN (Jacoby \& Gollock 2014, Jacoby et al. 2015) and was assessed as threatened in Canadian waters by the Canadian Committee on the Status of Endangered Wildlife in Canada (COSEWIC 2012).

To reach their spawning grounds in the Sargasso Sea from inland waterbodies, Atlantic eels often have to pass through hydroelectric power-generating

(C) The authors and Fisheries and Oceans Canada 2018. Open Access under Creative Commons by Attribution Licence. Use, distribution and reproduction are unrestricted. Authors and original publication must be credited. 
facilities. As a result, industries and utilities (especially hydropower) deal with constraints placed on them by regulators given the risk of migratory fishes being trapped or killed by impingement (i.e. fish being trapped against trash racks or screens) or entrainment (i.e. the diversion of fish through turbines or other water intake structures to downstream waters; Barnthouse 2013). Consequently, there is much interest in and need for devices or strategies that can be used to guide fish away from dangerous areas (e.g. turbine intakes) and towards safe paths (e.g. bypass channels). Although some eels survive passage through turbines, entrainment mortality is still common and regarded as a major factor impeding the recovery of the species. For example, on the St. Lawrence River, the outflow of the Laurentian Great Lakes, American eel need to pass through turbines at 2 large hydroelectric facilities, resulting in a cumulative annual turbine mortality of $39.5 \%$ (Verreault \& Dumont 2003). The eel outmigration period in the St. Lawrence River is unusually protracted, and as such these late-stage yellow eels do not undergo the physiological changes that are associated with the silver eel stage until they are closer to the St. Lawrence River estuary (McGrath et al. 2003a). Nevertheless, late-stage yellow eels must still undergo downstream migrations towards the estuary and encounter hazards along the way. A variety of strategies have been tested to guide American eel but there is still need to identify cost-effective strategies that achieve desirable outcomes that decrease passage-related mortalities and mitigate entrainment-related injury and mortality. In particular, significant challenges remain with guiding and safely passing outmigrating eels on large rivers, including the St. Lawrence and Ottawa rivers, where discharges and debris loading are high, as solutions that work at smaller plants for excluding eels from turbine intakes (e.g. screens or racks) are considered infeasible from an engineering perspective (Greig et al. 2006).

Across their range, eels are negatively phototactic, outmigrating (Lowe 1952, Smith \& Saunders 1955, Vøllestad et al. 1986) and generally more active at night (Helfman et al. 1983). In the St. Lawrence River system, peak migration coincides with the dark moon phase and increased cloud cover, although $\sim 25 \%$ of eels have been observed outmigrating during the day (McGrath et al. 2003b). Artificial lighting is one guidance approach for fishes that has shown some promise but lacked flexibility, limiting its widespread adoption (Brown 2000). Light was initially used to modify eel behaviour through negative phototaxis to improve fisheries capture success (Petersen 1906, Lowe 1952), and only more recently has light been used to deter eels away from areas that present risk of entrainment (Hadderingh \& Kema 1982). Early efforts to guide eels with light used mercury vapour bulbs (e.g. Haymes et al. 1984) that were unable to produce rapid flash rates (strobing) and offered only limited control over the spectra (colour) and intensity of the output. Over recent decades, light-emitting diodes (LEDs) have become ubiquitous as they provide new opportunities to manipulate the flash or strobe frequency, spectra, and intensity of light outputs, and to do so in real time. This flexibility allows light stimuli to match the spectral sensitivities of target species, possibly eliciting stronger behavioural responses. Modern LED systems can be programmed to cycle through different lighting regimes and provide a potential powerful new tool for behavioural guidance. Recently, white LED strobe lights were used to reduce European eel entrainment at a pumping station in the Netherlands (Kruitwagen 2014), and coloured LED strobe lights were tested on largemouth bass Micropterus salmoides (Sullivan et al. 2016) and juvenile white sturgeon Acipenser transmontanus (Ford et al. 2017, 2018), with promising results with respect to repelling fish from undesirable locations such as turbine intakes or attracting them towards safe bypasses.

Our objective was to test the effectiveness of an underwater, LED-based light guidance device (LGD) for behavioural guidance of American eel. Preliminary review of the existing literature on the visual physiology of adult Atlantic eels captured during spawning migrations revealed that they have strong retinal sensitivities to blue (480 $\mathrm{nm}$ ) and green (520 nm) light (based on electroretinograms; Pankhurst \& Lythgoe 1983), with the blue sensitivity developing concurrent with sexual maturation (Carlisle \& Denton 1959). Under dark conditions (e.g. at night or at depth), eel retinal cells are most sensitive to wavelengths around $520 \mathrm{~nm}$, while under light conditions, they are more sensitive to longer wavelengths (i.e. $550 \mathrm{~nm}$; Gordon et al. 1978). While white strobing lights have been demonstrated to be effective behavioural deterrents with eel (Kruitwagen 2014), only white and red light have been evaluated (Patrick et al. 1982; note that red light showed no response but this was consistent with spectral sensitivities for eel as red is $\sim 650 \mathrm{~nm}$ ).

Based on these reports, we decided to test the responses of late-stage yellow eels to 3 colours of light (blue at $480 \mathrm{~nm}$, yellow at $550 \mathrm{~nm}$, and full- 
spectrum white light) under dark conditions, at night, in dichotomous choice tests between LGD-illuminated versus unlit control arms of a y-maze. In addition, the LGD was programmed to strobe at both 1 flash $\mathrm{s}^{-1}(1 \mathrm{~Hz})$ and 30 flashes $\mathrm{s}^{-1}(30 \mathrm{~Hz})$ for each colour. We predicted that (1) eels would demonstrate avoidance of any light stimuli relative to dark conditions; (2) eels would demonstrate increased avoidance of wavelengths within their high sensitivity range (i.e. shorter wavelengths), and (3) higher strobe rates would improve the effectiveness of light as a deterrent. It is our expectation that results will provide further evidence that behavioural guidance of eels can be effective and will inform the design of field trials to test efficacy in a real-world application that has the potential to yield meaningful conservation gains for Atlantic eel populations.

\section{MATERIALS AND METHODS}

\section{Animal collection and transport}

We obtained 250 late yellow-stage American eels Anguilla rostrata captured by a commercial fisher via fyke net in the Bay of Quinte, Ontario (ON), Canada, between 10 and 17 October 2016 under a scientific collection permit from the Ontario Ministry of Natural Resources and Forestry (OMNRF) that specifically limited our sample size to 250 eels. Behavioural trials were conducted between 12 and 20 October. Late-stage yellow eels are large eels that could potentially begin (or already have begun) the physiological silvering process and outmigrate later during the autumn in which they were captured. Eels were transported to Environment Canada's Aquatic Life Research Facility (ALRF) at the Canadian Center for Inland Waters (CCIW) in Burlington, ON, in 3 separate shipments in an insulated and aerated $1000 \mathrm{l}$ tank. No mortalities occurred during transport. The first shipment consisted of 17 eels that were not included in the final dataset. Instead, these eels provided proof-of-concept for both their transport and the feasibility of our experimental design. Following testing, all 250 eels were returned to the Bay of Quinte and released near their site of capture. Throughout their captivity at the ALRF, the eels were held in darkness in covered $1000 \mathrm{l}$ semirecirculating tanks supplied with dechlorinated, filtered and UV-sterilized municipal water (City of Burlington, $\mathrm{ON}$ ) at temperatures ranging between 16.4 and $17.0^{\circ} \mathrm{C}$.

\section{Stimulus selection and light guidance device (LGD)}

The LED-based LGD used in this study is composed of 162 LED modules that can each produce red, green, and blue light at variable intensities and strobe at rates up to $40 \mathrm{~Hz}$ for 16 million different colour and intensity combinations (ATET-Tech, www. atet-tech.com; described by Ford et al. 2017, 2018). As outlined above, the device was programmed to emit blue $(480 \mathrm{~nm})$, yellow $(550 \mathrm{~nm})$, or full-spectrum white light, strobing at 1 or $30 \mathrm{~Hz}$ to match colour output to the retinal sensitivities of the eels and provide a range of strobe rates. The colour wavelengths were achieved by altering RGB (red, green, blue) saturation ratios in the LGD software interface. The eels were also exposed to a control treatment, consisting of the LGD present in the trial arena but not operating, generating 7 treatment combinations.

\section{Experimental setup and protocol}

Guidance trials were conducted in a dark green, fiberglass tank measuring $1.524 \times 6.096 \times 1.220 \mathrm{~m}$ (width $\times$ length $\times$ depth) filled with water to a depth of $50 \mathrm{~cm}$. Due to the size of the tank, we could not conduct the experiment in the ALRF facilities proper and instead used a loading dock that was not air conditioned. Consequently, water in the test tank was slightly warmer $\left(18.1\right.$ to $\left.19.3^{\circ} \mathrm{C}\right)$ than the water in the holding tanks. The tank was equipped with a standard-sized $2.44 \mathrm{~m} \times 1.22 \mathrm{~m} \times 1.27 \mathrm{~cm}$ (length $\times$ height $\times$ width) sheet of grey PVC at one end to create a ymaze (Fig. 1a). Y-maze setups are commonly used to provide test animals with a dichotomous choice between a stimulus area and a control refuge area, or between 2 alternative stimuli, located in either 'arm' or chamber of the y-maze. In this experiment, the eels were given a choice between one empty arm while the other arm contained the LGD. The LGD was moved between arms after every block of replicate trials (i.e. after each of the 7 LGD settings had been presented to 7 different eels) to control for the possibility of inherent side biases in the eels.

Individual eels were introduced into the tank in a central acclimation area partitioned with plastic vexar mesh barrier screens. The acclimation area was $1 \mathrm{~m}$ long, with 1 barrier positioned $1 \mathrm{~m}$ from the opening of the y-maze. Eels were allowed to acclimate for $4 \mathrm{~min}$, after which the LGD treatment was activated and the eels were allowed $1 \mathrm{~min}$ of exposure before removal of the barrier screens. In the control trials, eels were left in the acclimation areas 

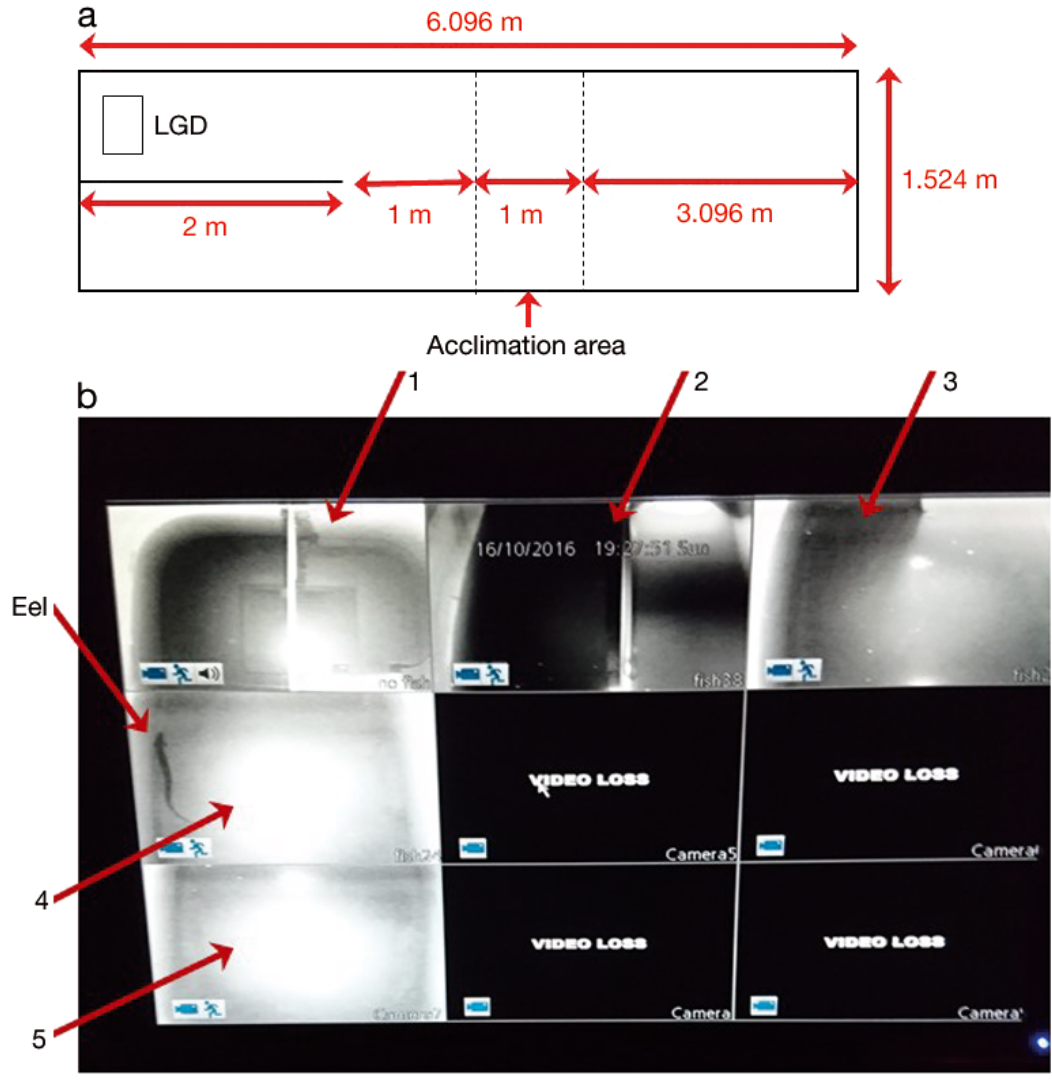

Fig. 1. (a) Schematic diagram of the experimental y-maze setup, including the central acclimation area before the barrier screens (dashed lines) were removed. The LED-based light guidance device (LGD) was moved to the other side of the y-maze partition after each replicate block of trials. The tank was filled to a depth of $50 \mathrm{~cm}$ with water and the temperature ranged from 18.1 to $19.3^{\circ} \mathrm{C}$ during the trials. (b) Image of a computer monitor displaying the fields of view of 5 overhead infrared security cameras. Images are numbered from the y-maze (1) to the opposite end of the tank (5). Data for analyses were transcribed from the video from Camera 3, which recorded the acclimation area and the entrance to the y-maze. An eel is pictured in the display from Camera 4

for 5 min periods without the LGD functioning for the last minute. Following the removal of the barriers, the eels were allowed to move freely throughout the $\mathrm{y}$-maze for $5 \mathrm{~min}$. At the end of each trial (10 min total elapsed time), the eels were removed, sedated using clove oil $\left(0.4 \mathrm{ml} \mathrm{l}^{-1}\right.$ of a $10 \%$ clove oil-ethanol solution), measured (total length, $\mathrm{cm}$ ) and weighed (kg). Eels were allowed to recover from sedation before being placed in separate holding tanks to prevent repeated testing of individuals.

\section{Data collection and analyses}

All trials $(n=233)$ were recorded as digital, infrared video using an array of 5 security cameras (PRO642 camera units connected to a DVR9-4200 9
Channel 960H Digital Video Recorder; Swann Communications) suspended over the tank (Fig. 1b). The videos were stored in duplicate on two 2 TB solidstate external hard drives and reviewed by a single observer (C.K.E.) for consistency. Measures recorded from the video consisted of (1) initial direction of movement (towards or away from the y-maze, or no initial choice if the eel did not leave the acclimation area within $45 \mathrm{~s}$ ); (2) first side of the y-maze entered; (3) latency (s) to first entry; (4) latency to entry into the second side of the y-maze; (5) number of entries on each side; (6) number of entries to the first side before entering the second side; and (7) time spent on each side of the $y$-maze. From these measures, we also calculated (8) the mean time spent in each side per visit (the ratio of measures 7 and 6 ).

To identify any potential side bias or effect of the experimental y-maze setup itself on eel behaviours, we separated the control trials for independent analyses. The complete dataset was then analyzed in 3 components: (1) Binary response variables (whether or not initial movement was towards the y-maze; whether or not the first side entered contained the LGD) were analyzed as generalized linear models with binomial error distributions and Wald's $\chi^{2}$ test statistic. The binary responses were further examined in odds-ratio tests to identify which LGD settings were most likely to elicit either attraction or avoidance behaviours; (2) count-based data (number of entries to each side) were analyzed as the binomial data but with Poisson error distributions; while (3) continuous responses (latencies to entry and time spent in each side) were examined against normal distributions using the ANOVA F-statistic. In all tests, LGD setting was a categorical factor, eel size metrics (total length and mass) were included as linear covariates, and we used the Type II sum of squares method ('car' package; Fox \& Wiesberg 2011). When statistical differences in behavioural responses were attributed to LGD settings (at $\alpha=0.1$ ), we used Dunnett's post hoc test ('multcomp' package; Hothorn et al. 2008) to determine which settings, if any, differed from the control. All analyses and figures were generated using R v.3.3.1 (R Core Team 2016). 


\section{RESULTS}

\section{Sample size and control trials}

Out of 233 American eels Anguilla rostrata tested, 2 trials (1 control; 1 white light at $30 \mathrm{~Hz}$ ) were not recorded adequately by our video equipment and were discarded. Final sample sizes for each of our 7 treatments, as well as mean total length $(\mathrm{cm})$ and mass $(\mathrm{kg})$ of the eels in each treatment group are listed in Table 1. In no statistical test did either measure of eel size (total length and/or mass) have a significant effect as a linear covariate on the behavioural response (all p > 0.05), so we removed these variables from further analyses.

Based on the outcomes of the control trials $(n=33)$, the eels that initially moved towards the y-maze ( $\mathrm{n}=$ 21) did not demonstrate either a significant side bias (preference for e.g. left vs. right: 9 and 12, respectively) or an attraction or avoidance of the LGD unit itself when it was not operating (all side comparisons relative to where the LGD was situated, $\mathrm{p}>0.05$ ).

Table 1. Total sample sizes, number of replicates on each side of the y-maze, and mean values $( \pm 1 \mathrm{SD})$ of total length and mass for American eels exposed to each of 7 treatments

\begin{tabular}{|lccccc|}
\hline Treatment & $\mathrm{n}$ & $\begin{array}{c}\text { Left } \\
\text { side } \\
\text { trials }\end{array}$ & $\begin{array}{c}\text { Right } \\
\text { side } \\
\text { trials }\end{array}$ & $\begin{array}{c}\text { Total } \\
\text { length } \\
(\mathrm{cm})\end{array}$ & $\begin{array}{c}\text { Mass } \\
(\mathrm{kg})\end{array}$ \\
\hline Control & 33 & 16 & 17 & $85.4 \pm 4.6$ & $1.41 \pm 0.26$ \\
Blue, $1 \mathrm{~Hz}$ & 33 & 16 & 17 & $87.8 \pm 6.9$ & $1.53 \pm 0.32$ \\
Blue, 30 Hz & 33 & 16 & 17 & $86.2 \pm 5.6$ & $1.46 \pm 0.28$ \\
White, $1 \mathrm{~Hz}$ & 33 & 16 & 17 & $86.2 \pm 4.3$ & $1.45 \pm 0.26$ \\
White, 30 Hz & 33 & 16 & 17 & $86.1 \pm 6.8$ & $1.45 \pm 0.28$ \\
Yellow, $1 \mathrm{~Hz}$ & 33 & 16 & 17 & $86.8 \pm 5.9$ & $1.47 \pm 0.30$ \\
Yellow, 30 Hz & 33 & 16 & 17 & $86.3 \pm 6.0$ & $1.44 \pm 0.27$ \\
\hline
\end{tabular}

However, more eels initially moved towards the ymaze $(21$ out of $33,64 \%$ ) than away from it (8 out of $33,24 \%)$, and the remaining 4 eels made no initial directional movement (12\%; Table 2). Collectively, these numbers suggest that the eels were demonstrating exploratory behaviours directed at the $y$-maze structure itself, and not the LGD unit in the ymaze.

\section{Behavioural responses to coloured LED strobe lights}

LGD setting did not influence the direction of initial movement (Fig. 2a), with 158 eels moving toward the y-maze, 64 moving away, and 9 demonstrating no initial preference. Odds ratio comparisons indicate that, relative to the control treatment, eels demonstrated slightly greater odds of first approaching the y-maze when exposed to any colour of light strobing at $1 \mathrm{~Hz}$, but had uniformly lower odds of approaching the y-maze when exposed to any colour of light strobing at $30 \mathrm{~Hz}$, with the smallest odds associated with yellow light at $30 \mathrm{~Hz}$ (Table 2, left columns).

LGD setting significantly influenced which y-maze arm was first entered by the eels (Wald's $\chi^{2}{ }_{6}=22.5$, $\mathrm{p}<0.001$ ), with significant differences between each LGD setting and the control treatment (all $\mathrm{p}<0.05$; Fig. 2b). Of the 9 eels (out of 233) that demonstrated no initial preference, 4 failed to enter either side of the y-maze during their 5 min trials, and of those four, two occurred during control trials. Every LGD setting was associated with lower odds of entering the LGD-side of the y-maze first, as compared to the control treatment (Table 2, right columns).

Latency to enter either the $\operatorname{LGD}\left(F_{6,50}=1.65, \mathrm{p}>\right.$ 0.1 ; Fig. 3a) or 'dark' control $\left(F_{6,163}=0.36, \mathrm{p}>0.9\right.$;

Table 2. Initial directions of movement (left columns) and initial side of y-maze entry (right columns) of eels exposed to the different light guidance device (LGD) settings and control treatment. Odds ratios are calculated by dividing the odds associated with a light treatment by the odds associated with the control treatment. NA: not applicable because the eel moved neither toward nor away from the maze

\begin{tabular}{|c|c|c|c|c|c|c|c|c|c|c|}
\hline \multirow{2}{*}{ LGD Setting } & \multicolumn{5}{|c|}{ Initial direction of movement relative to y-maze } & \multirow{2}{*}{ LGD } & \multicolumn{3}{|c|}{ First side of entry } & \multirow[b]{2}{*}{$\begin{array}{l}\text { Odds } \\
\text { ratio }\end{array}$} \\
\hline & Towards & Away & NA & $\begin{array}{c}\text { Odds } \\
\text { (towards) }\end{array}$ & $\begin{array}{l}\text { Odds } \\
\text { ratio }\end{array}$ & & Control & NA & $\begin{array}{l}\text { Odds } \\
\text { (LGD) }\end{array}$ & \\
\hline Control & 21 & 8 & 4 & 2.625 & - & 18 & 13 & 2 & 1.385 & - \\
\hline Blue, $1 \mathrm{~Hz}$ & 26 & 7 & 0 & 3.714 & 1.41 & 8 & 25 & 0 & 0.320 & 0.23 \\
\hline Blue, $30 \mathrm{~Hz}$ & 22 & 10 & 1 & 2.200 & 0.84 & 3 & 29 & 1 & 0.103 & 0.07 \\
\hline Yellow, $1 \mathrm{~Hz}$ & 23 & 8 & 2 & 2.875 & 1.09 & 8 & 24 & 1 & 0.333 & 0.24 \\
\hline Yellow, $30 \mathrm{~Hz}$ & 20 & 13 & 0 & 1.538 & 0.59 & 8 & 25 & 0 & 0.320 & 0.23 \\
\hline White, $1 \mathrm{~Hz}$ & 24 & 8 & 1 & 3.000 & 1.14 & 9 & 24 & 0 & 0.375 & 0.27 \\
\hline White, $30 \mathrm{~Hz}$ & 22 & 10 & 1 & 2.200 & 0.84 & 3 & 30 & 0 & 0.100 & 0.07 \\
\hline
\end{tabular}



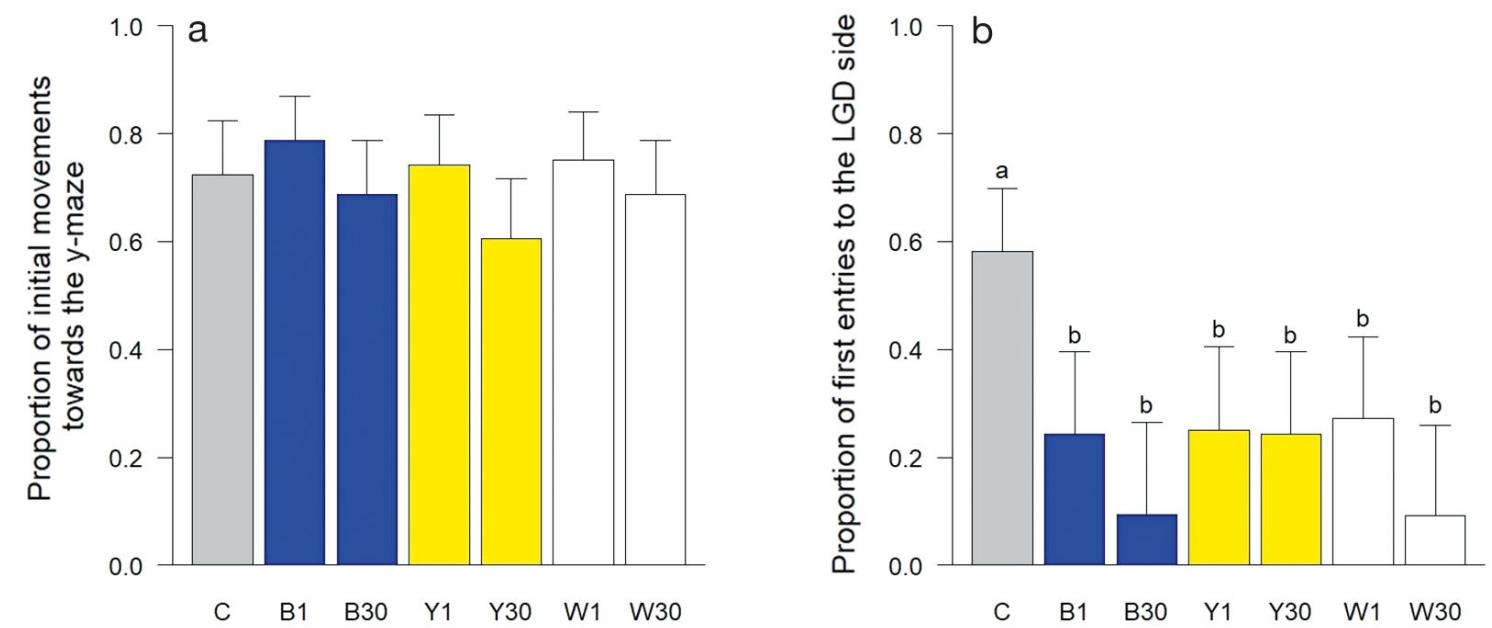

Fig. 2. Proportions of trials ( $+1 \mathrm{SE})$ in each treatment where (a) the initial direction of movement was towards the $y-m a z e$ and (b) where the first side of the y-maze entered contained the LGD. Letters denote significant differences $(p<0.05)$ between LGD settings and the control treatment from Dunnett's post hoc testing. C: control treatment; B1: blue light strobing at $1 \mathrm{~Hz}$; B30: blue light strobing at $30 \mathrm{~Hz}$; Y1: yellow light strobing at $1 \mathrm{~Hz}$; Y30: yellow light strobing at $30 \mathrm{~Hz}$; W1: full-spectrum white light strobing at $1 \mathrm{~Hz}$; W30: full spectrum white light strobing at $30 \mathrm{~Hz}$
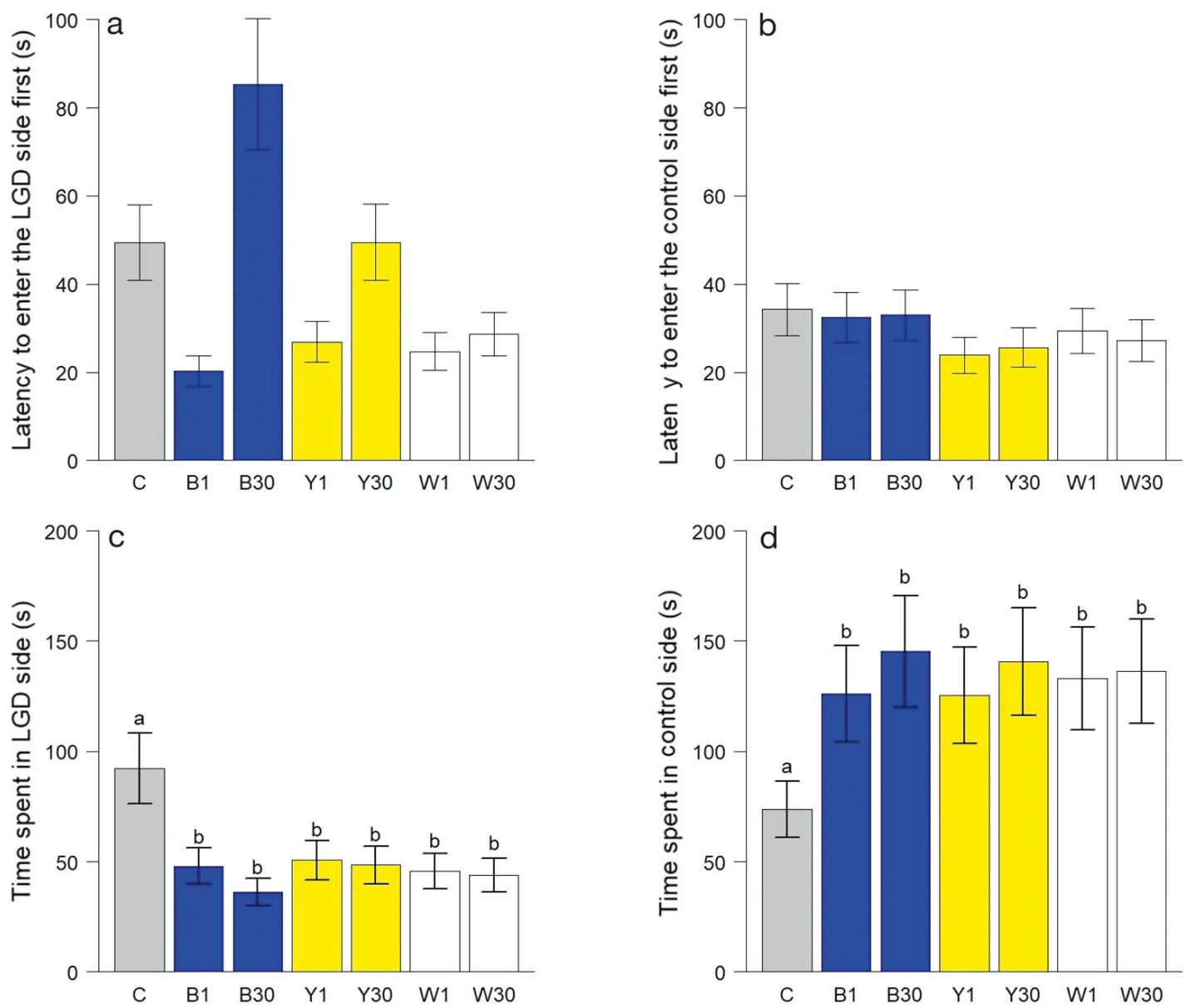

Fig. 3. Latency (s) to first entry of the y-maze side (a) with the LGD or (b) without the LGD, and total time (s) spent on the (c) LGD or (d) control sides in each 5 min trial. Letters denote significant differences $(p<0.05)$ between LGD settings and the control treatment from Dunnett's post hoc testing. Data are means \pm 1 SE. See Fig. 2 for treatment codes 
Fig. 3b) sides of the y-maze were not influenced by LGD setting, although blue light at $30 \mathrm{~Hz}$ elicited the longest mean time (Fig. 3a) and the eels did tend to demonstrate greater latencies to enter the LGD side first compared to the dark side (Fig. 3a,b).

Time spent in both the LGD side of the y-maze $\left(F_{6,220}=4.51, \mathrm{p}<0.001\right.$; Fig. 3c $)$ and the dark side of the y-maze $\left(F_{6,220}=4.41, \mathrm{p}<0.001\right.$; Fig. $\left.3 \mathrm{~d}\right)$ differed significantly between LGD settings. Time on the LGD side was consistently less for all of the LGD settings compared to the control (no light) setting (all $\mathrm{p}<$ 0.01; Fig. 3c), while the time on the dark side was consistently greater for all of the LGD settings compared to the control (no light) setting (all $\mathrm{p}<0.01$; Fig. 3d).

LGD setting had a nearly significant effect on the number of entries to the side of the y-maze containing the LGD $\left(\chi_{6}^{2}=12.05, p=0.061\right)$. Post hoc testing revealed a significant difference in the number of entries between the control (no light) treatment and blue light at $30 \mathrm{~Hz}$ ( $\mathrm{p}<0.05$; Fig. 4a), and on average, eels entered the LGD side more often when it was not operational during the control treatments (Fig. 4a). By contrast, the LGD settings had a statistically significant effect on the number of entries to the dark side of the $y$-maze $\left(\chi^{2}{ }_{6}=12.9, p<0.05\right)$, with significant pairwise differences between every LGD setting and the control treatment (all p $<0.01$; Fig. 4b) such that the dark arm was entered more often when the LGD was operational.

Considering time spent in either side of the y-maze on a per-entry basis, LGD setting did not influence the average time per visit on either the LGD $\left(F_{6,163}=\right.$ $1.59, \mathrm{p}>0.1$; Fig. $4 \mathrm{c})$ or dark $\left(F_{6,211}=0.91, \mathrm{p}>0.4\right.$; Fig. 4d) side of the y-maze. However, eels tended to spend more time per entry on the dark side compared to the LGD side (Fig. 4c,d).
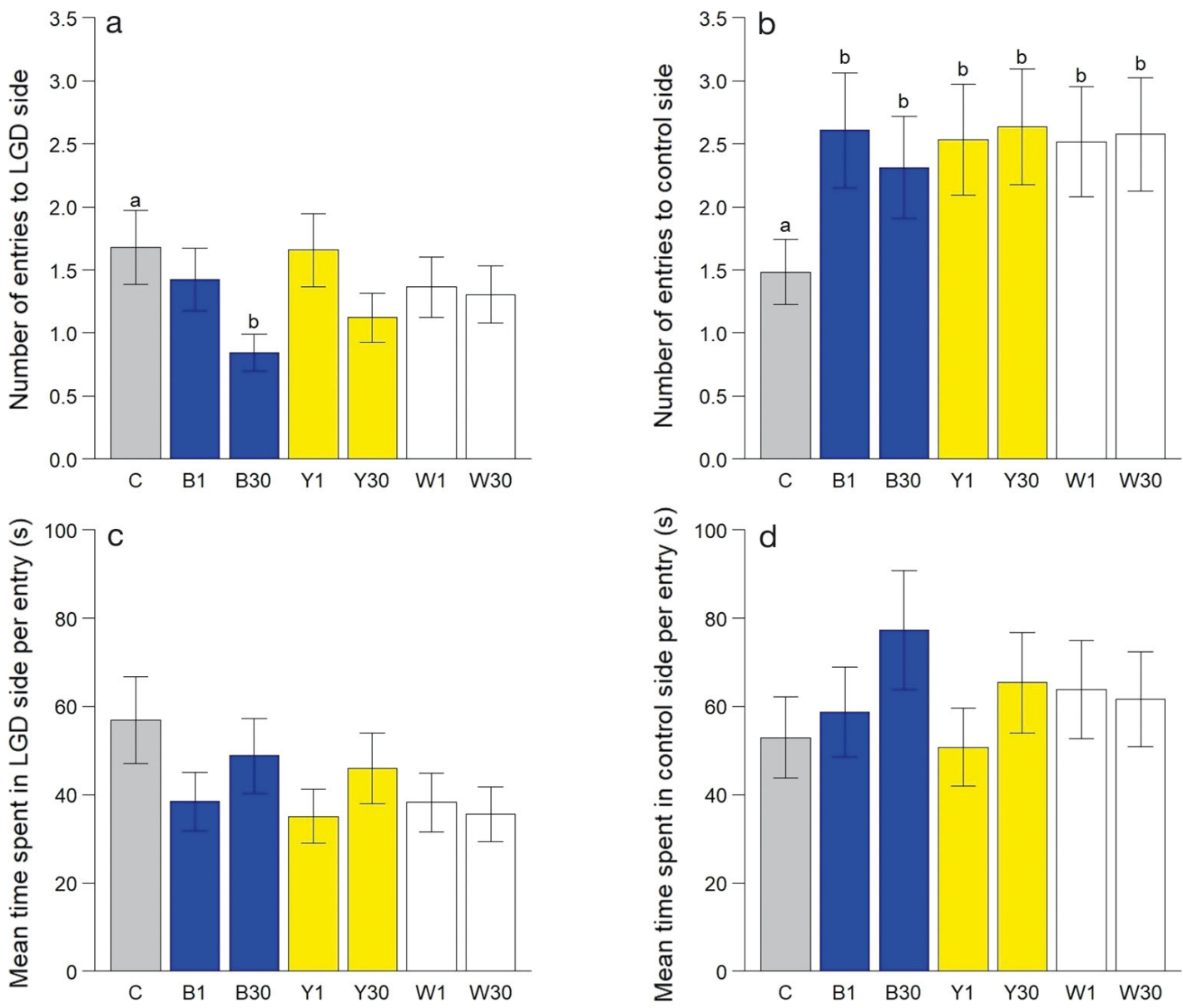

Fig. 4. Mean ( $\pm 1 \mathrm{SE})$ numbers of entries to (a) the side of the y-maze containing the LGD and (b) the control side of the y-maze, and mean amount of time (s) spent per entry on the y-maze side (c) with the LGD or (d) without the LGD. Letters denote significant differences $(\mathrm{p}<0.05)$ between LGD settings and the control treatment from Dunnett's post hoc testing. See Fig. 2 for treatment codes 


\section{DISCUSSION}

In general, the late-stage yellow American eels assessed in this project did not demonstrate side biases in the testing tank although they did demonstrate attraction towards the structure provided by the y-maze partition. Despite a tendency to approach the y-maze independent of whether or not the LGD was operating, they tended to avoid entering the illuminated arm of the y-maze initially. However, most of those that initially entered the control (unilluminated) arm eventually entered the illuminated arm. The eels did not differ in the time (latency) to enter either y-maze arm, although they did enter the control (dark) arm significantly more often than the illuminated arm. They also did not differ in their mean times per visit to either the LGD or control arms of the y-maze.

Compared to the unilluminated control trials, the eels appeared to demonstrate the greatest levels of aversion to blue light strobing at $30 \mathrm{~Hz}$, although they all entered the control arm more often when the LGD was operating than during the unilluminated control trials. This is consistent with the maximum sensitivity to blue spectrum light measured in sexually mature silver eels (Hope et al. 1998). Based on their initial directions of movement, eels were more likely to move away from the y-maze when exposed to any colour of light strobing at $30 \mathrm{~Hz}$. Collectively, these observations indicate that adult eels are most likely to avoid blue light strobing at $30 \mathrm{~Hz}$, although we cannot conclusively state that one colour of light is more effective at achieving avoidance behaviour than another, relative to unilluminated controls. Furthermore, the avoidance behaviours we observed seemed to attenuate over the 5 min trials, suggesting that light may be most effective at guiding eels while they are moving, and ineffective at guiding eels in more static contexts. Ultimately, the effectiveness of behavioural guidance strategies appears to depend on the interaction of previous experiences of individual fish with proximal environmental factors (Goodwin et al. 2014), notably velocity of flow in this case. Under natural conditions as eels move rapidly downstream with the water current, we predict that the repellent effects of LED light described above should be magnified and result in outmigrating eels sharply diverting their course away from light stimuli.

Body length or mass were not important contributors to any of the models developed in this study, but it is important to note that the test subjects most likely came from a conservation stocking effort (Pratt \& Threader 2011), and as a result there was little vari- ation in the size of eels used in this experiment. As eels become sexually mature during the transition from yellow to silver stages of their life history, studies have demonstrated that their photosensitivity changes from being most sensitive to green light $(\sim 520 \mathrm{~nm})$ to blue light $(\sim 480 \mathrm{~nm})$, concurrent with leaving freshwater or estuarine habitats and entering the open ocean as silver eels (Carlisle \& Denton 1959, Andjus et al. 1998, Hope et al. 1998). The eels in the present study were from a population that was $\sim 75 \%$ likely to silver and outmigrate that fall, based on tagging studies of eels captured by the same commercial fisherman from a similar time period in previous years (A. Mathers, OMNRF, pers. comm.). It is likely that the individuals we tested were mostly late-stage yellow eels, although some may have been in the early silver stage with slightly different spectral sensitivities, which might explain the observed differences in the blue, yellow, and white light avoidance.

This research adds to a growing body of literature demonstrating that light can be used to guide or deter Atlantic eels (e.g. Lowe 1952, Hadderingh et al. 1992, Cullen \& McCarthy 2000, Kruitwagen 2014), including on large rivers such as the St. Lawrence River (Versar 2009). However, there are a few (mostly unpublished) contradictory studies in which eels did not demonstrate avoidance of light (e.g. Berg 1985, cited in Hadderingh et al. 1992). It is important to note that this research was completed in a static water scenario. Eels tend to move downstream in the highest water velocities during elevated spring discharges, and velocity can influence the effectiveness of light as a guidance tool, not only for eels (Hadderingh et al. 1999, Piper et al. 2015) but for other fish species as well (Nestler et al. 2008).

Future research on the use of LED lights, including the light guidance device we tested, should be scaled up and implemented under more natural settings. Based on our observations, the most parsimonious experimental design involves exposing free-swimming eels to as few as 2 light treatments: blue light strobing at $30 \mathrm{~Hz}$ and unilluminated control trials. While our experimental design allowed us to identify differences in response to light strobing at 1 vs. $30 \mathrm{~Hz}$, it is possible that eels cannot distinguish between $30 \mathrm{~Hz}$ and constant illumination. Constant illumination has been successful in guiding or deterring eels (e.g. Lowe 1952, Hadderingh et al. 1992), but so has strobing light (Patrick et al. 1982, Kruitwagen 2014). The improved deterrence in our study at $30 \mathrm{~Hz}$ suggests that there may be guidance advantages to strobing light, in addition to other potential benefits including less attraction for other fishes and lower 
energy costs. Future testing could also incorporate intermediate strobing rates (e.g. $5 \mathrm{~Hz}, 10 \mathrm{~Hz}$, etc.) and continuous illumination, although these would require replicating our experimental conditions to enable comparison to the observations we report here.

Acknowledgements. Lisa O'Connor and Evan Timusk (Fisheries \& Oceans Canada) provided technical assistance during experimental trials and transported the eels between Bay of Quinte, ON, and Burlington, ON. Gary Mitchell obtained the eels. Bill Sloan (OMNRF) provided the testing tank, and Alastair Mathers and Colin Lake expedited our scientific collection permit from OMNRF. All work was in accordance with the guidelines of the Canadian Council on Animal Care and Carleton University Animal Care Protocol \# 102925. Funding was provided by the Canada Research Chairs Program and an NSERC Discovery grant to S.J.C. and Fisheries \& Oceans Canada Partnership Project \#CU305126 .

\section{LITERATURE CITED}

Andjus RK, Damjanović I, Gačić Z, Konjević DJ, Andjus PR (1998) Electroretinographic evaluation of spectral sensitivity in yellow and silver eels (Anguilla anguilla). Vis Neurosci 15:923-930

Barnthouse LW (2013) Impacts of entrainment and impingement on fish populations: a review of the scientific evidence. Environ Sci Policy 31:149-156

Berg R (1985) Turbinenbedingte Schäden an FischenBericht über Versuche am Laufkraftwerk Neckarzimmern. Gutachten Fischereiforschungsstelle Baden-Würtemberg

Brown R (2000) The potential of strobe lighting as a costeffective means for reducing impingement and entrainment. Environ Sci Policy 3:405-416

Cairns DK, Chaput G, Poirier LA, Avery TS and others (2014) Recovery potential assessment for the American eel (Anguilla rostrata) for Eastern Canada: life history, distribution, reported landings, status indicators, and demographic parameters. DFO Canadian Science Advisory Secretariat Research Document 2013/134. DFO, Ottawa

Carlisle DB, Denton EJ (1959) On the metamorphosis of the visual pigments of Anguilla anguilla (L.). J Mar Biol Assoc UK 38:97-102

COSEWIC (2012) COSEWIC assessment and status report on the Americal Eel Anguilla rostrata in Canada. http:// publications.gc.ca/collections/collection_2013/ec/CW69 -14-458-2012-eng.pdf (accessed 31 July 2017)

Cullen P, McCarthy TK (2000) The effects of artificial light on the distribution of catches of silver eel, Anguilla anguilla (L.), across the Killaloe eel weir in the lower River Shannon. Biol Environ 100B:165-169

Dekker W, Beaulaton L (2016) Climbing back up what slippery slope? Dynamics of the European eel stock and its management in historical perspective. ICES J Mar Sci 73: 5-13

Feunteun E (2002) Management and restoration of European eel population (Anguilla anguilla): an impossible bargain. Ecol Eng 18:575-591
Ford MI, Elvidge CK, Baker D, Pratt TC and others (2017) Evaluating a light-louver system for behavioural guidance of age-0 white sturgeon. River Res Appl 33:1286-1294

Ford MI, Elvidge CK, Baker D, Pratt TC and others (2018) Preferences of age- 0 white sturgeon for different colours and strobe rates of LED lights may inform behavioural guidance strategies. Environ Biol Fishes 101:667-674

Fox J, Wiesberg S (2011) An R companion to applied regression, 2nd edn. Sage Publications, Thousand Oaks, CA

Goodwin RA, Politano M, Garvin JW, Nestler JM and others (2014) Fish navigation of large dams emerges from their modulation of flow field experience. Proc Natl Acad Sci USA 111:5277-5282

Gordon J, Shapley RM, Kaplan E (1978) The eel retina. Receptor classes and spectral mechanisms. J Gen Physiol 71:123-138

Greig L, Parnell IJ, Marmorek DR (2006) Developing an action plan for American eels in the St. Lawrence RiverLake Ontario Region: decision analysis. Prepared by ESSA Technologies Ltd. for Hydro Quebec, Fisheries and Oceans Canada, Ontario Ministry of Natural Resources, Ontario Power Generation, and the US Fish and Wildlife Service http://publications.gc.ca/collections/collection_ 2013/mpo-dfo/Fs70-5-2011-046-eng.pdf

Hadderingh RH, Kema NV (1982) Experimental reduction of fish impingement by artificial illumination at Bergum power station. Int Rev Gesamten Hydrobiol 67:887-890

Hadderingh RH, Van Der Stoep JW, Hagraken JM (1992) Deflecting eels from water inlets of power stations with light. Ir Fish Invest Ser A Freshw 36:78-87

*Hadderingh RH, Van Aerssen GHFM, De Beijer RFLJ, Van Der Velde G (1999) Reaction of silver eels to artificial light sources and water currents: an experimental deflection study. River Res Appl 15:365-371

*Haymes GT, Patrick PH, Onisto LJ (1984) Attraction of fish to mercury vapour light and its application in a generating station forebay. Int Rev Hydrobiol 69:867-876

*Helfman GS, Stoneburner DL, Bozeman EL, Christian PA, Whalen R (1983) Ultrasonic telemetry of American eel movements in a tidal creek. Trans Am Fish Soc 112: $105-110$

Hope AJ, Partridge JC, Hayes PK (1998) Switch in rod opsin gene expression in the European eel, Anguilla anguilla (L.). Proc R Soc B 265:869-874

*Hothorn T, Bretz F, Westfall P (2008) Simultaneous inference in general parametric models. Biom J 50:346-363

* Jacoby D, Gollock M (2014) Anguilla anguilla. The IUCN Red List of Threatened Species 2014: e.T60344A458 33138. http://dx.doi.org/10.2305/IUCN.UK.2014-1.RLTS. T60344A45833138.en

Jacoby DM, Casselman JM, Crook V, DeLucia MB and others (2015) Synergistic patterns of threat and the challenges facing global anguillid eel conservation. Glob Ecol Conserv 4:321-333

*Kruitwagen G (2014) Research at IJmuiden lock complex provides unique insight in fish guidance. WIT Trans State Art Sci Eng 71:141-151

Lowe RH (1952) The influence of light and other factors on the seaward migration of the silver eel (Anguilla anguilla L.). J Anim Ecol 21:275-309

McGrath KJ, Bernier J, Ault S, Dutil JD, Reid K (2003a) Differentiating downstream migrating American eels Anguilla rostrata from resident eels in the St. Lawrence River. In: American Fisheries Society Symposium. American Fisheries Society, Bethesda, MD, p 315-327 
McGrath KJ, Desrochers D, Fleury C, Dembeck JW (2003b) Studies of upstream migrant American eels at the MosesSaunders Power Dam on the St. Lawrence River near Massena, New York. In: American Fisheries Society Symposium. American Fisheries Society, Bethesda, MD, p 153-166

Nestler JM, Goodwin RA, Smith DL, Anderson JJ, Li S (2008) Optimum fish passage and guidance designs are based in the hydrogeomorphology of natural rivers. River Res Appl 24:148-168

Pankhurst NW, Lythgoe JN (1983) Changes in vision and olfaction during sexual maturation in the European eel Anguilla anguilla (L.). J Fish Biol 23:229-240

Patrick PH, Sheehan RW, Sim B (1982) Effectiveness of a strobe light eel exclusion scheme. Hydrobiologia 94: 269-277

Petersen CGJ (1906) The influence of light on the migration of the eel. Rep Danish Biol Stn 14:2-9

Piper AT, Manes C, Siniscalchi F, Marion A, Wright RM, Kemp PS (2015) Response of seaward-migrating European eel (Anguilla anguilla) to manipulated flow fields. Proc R Soc B 282:20151098

Pratt TC, Threader RW (2011) Preliminary evaluation of a large-scale American eel conservation stocking experiment. N Am J Fish Manage 31:619-628

Pratt TC, Bradford RG, Cairns DK, Castonguay M, Chaput G, Clarke KD, Mathers A (2014) Recovery potential

Editorial responsibility: Brendan Godley,

University of Exeter, Cornwall Campus, UK assessment for the American eel (Anguilla rostrata) in eastern Canada: functional description of habitat. DFO Canadian Science Advisory Secretariat Research Document 2013/132. DFO, Ottawa

R Core Team (2016) R: a language and environment for statistical computing. R Foundation for Statistical Computing, Vienna. https://www.R-project.org/

Smith MW, Saunders JW (1955) The American eel in certain fresh waters of the Maritime provinces of Canada. J Fish Res Board Can 12:238-269

Sullivan BG, Wilson ADM, Gutowsky LFG, Patrick PH, Sills M, Cooke SJ (2016) The behavioral responses of a warmwater teleost to different spectra of light-emitting diodes. N Am J Fish Manage 36:1000-1005

Verreault G, Dumont P (2003) An estimation of American eel escapement from the upper St. Lawrence River and Lake Ontario in 1996 and 1997. In: American Fisheries Society Symposium. American Fisheries Society, Bethesda, MD, p 243-251

Versar (2009) Review of technologies for guiding, capturing, holding, transporting, and monitoring outmigrating eels. Prepared for New York Power Authority by Versar, Inc., Columbia, MD, p 384

*Vøllestad LA, Jonsson B, Hvidsten NA, Næesje TF, Haraldstad Ø, Ruud-Hansen J (1986) Environmental factors regulating the seaward migration of European silver eels (Anguilla anguilla). Can J Fish Aquat Sci 43:1909-1916

Submitted: September 5, 2017; Accepted: January 28, 2018 Proofs received from author(s): March 8, 2018 